\title{
PERANCANGAN PERMUKIMAN KAMPUNG AUR DI KOTA MEDAN (DENGAN PENDEKATAN ARSITEKTUR PERILAKU DAN LINGKUNGAN)
}

\author{
Dicky Andrea Sembiring \\ Program Studi Magister Teknik Arsitektur Universitas Sumatera Utara \\ Jl. Perpustakaan St. J07 Building, Medan, 20155, Indonesia \\ *Email: dickyandrea45@gmail.com
}

\begin{abstract}
ABSCTRACT
Kampung Aur is one of the densely populated settlements situated on the banks of the Deli River, Medan. So far there have been several type of solution to the matter regarding densely populated settlements ranging from forced evictions, construction of new settlements in the form of flat / rusunawa and kampung improvement program. It can be said, the government began to realize that the problem can not be solved with one-way system. There must be communication with the slum dwellers. This then prompted the authors to make the planning of Kampung Aur settlements with environmental-behavioral approach to be the title of his thesis. This study aims to produce a design of settlement which can accommodate social and cultural aspects of society through environmental behavior approach. To achieve these objectives, participatory observation will be conducted on each dominant communities that exist on the site. Through these observations it will be known how the environmental setting and behavior setting works in Kampung Aur. The data of environmental setting and behavior setting will then be processed to produce design criteria of Kampung Aur Settlement.

From this research it was found that there are two dominant tribe in Kampung Aur, the Chinese and Minang. Minang communities further demonstrate characteristics that have a high degree of territoriality and low privacy, while Chinese are just the opposite. Based on the characteristics of the existing society, a desing can be produced in accordance with the behavior of each communities in Kampung Aur.
\end{abstract}

Keywords: Slum, Environmental Behavior, Aur Settlement.

\section{PENDAHULUAN}

Permukiman Kampung Aur merupakan salah satu permukiman padat penduduk yang terletak di bantaran Sungai Deli, Kelurahan Kampung Aur, Medan. Jika berbicara mengenai permukiman Kampung Aur, maka pandangan umum yang muncul adalah permukiman padat penduduk yang tidak teratur, bangunan semi permanen, kurang memperhatikan kebersihan serta legalitas bangunan yang masih dipertanyakan.

Munculnya permukiman kumuh di kawasan pusat kota seperti ini sebenarnya tidak hanya terjadi di Kota Medan saja. Kasus seperti ini juga terjadi hampir di seluruh kota-kota besar yang ada di Indonesia. Sebagai contohnya dapat dlihat pada permukiman kumuh sepanjang aliran Sungai Ciliwung di Jakarta, permukiman kumuh di bantaran Sungai Code di Yogyakarta, permukiman kumuh di bantaran Sungai Musi di Palembang dan banyak contoh sejenis lainnya.

Sejauh ini sudah ada beberapa bentuk penyelesaian yang dilaksanakan terkait masalah ini. Mulai dari hal yang sifatnya sangat teknis seperti penggusuran dan pembangunan rusun/rusunawa di daerah baru, kemudian mulai menerapkan prinsip tri-daya (sosial, ekonomi dan fisik-lingkungan) pada program KIP di tahun 1969, hingga pada rencana terbaru pemerintah yang sudah memberikan 3 (tiga) kemungkinan penyelesaian terhadap masalah ini yaitu melalui pelayakan permukiman, peremajaan (perbaikan kawasan dimana masyarakat harus pindah secara temporer) dan permukiman kembali (disini masyarakat akan direlokasi menuju permukiman baru yang telah dibangun). Dapat dikatakan, pemerintah mulai menyadari bahwa permasalahan permukiman kumuh ini tidak dapat diselesaikan dengan sistem satu arah. Harus ada komunikasi dengan 
penduduk permukiman kumuh. Banyak aspek yang harus menjadi perhatian terutama aspek sosial-budaya masyarakat (hubungan masyarakat dengan lingkungannya).

Hal ini juga sejalan dengan apa yang disampaikan oleh Rapoport (1977) bahwa hubungan antara manusia dan lingkungan sebenarnya tidaklah bersifat mekanistis belaka. Hubungan ini penuh makna, simbol dan normanorma, merupakan kewajiban kita untuk memahami makna-makna tersebut, agar proses penciptaan lingkungan selanjutnya tidak terjebak dalam proses besar dehumanisasi yang sedang berlangsung.

Kondisi ini jugalah yang terjadi pada permukiman Kampung Aur. Berdasarkan observasi awal yang dilakukan, dapat dilihat kerumitan masalah yang ada di sini. Mulai dari masalah fisik seperti ketidaklayakan fisik bangunan dan sanitasi, tingkat kepadatan yang terlalu tinggi, hingga masalah sosial budaya masyarakat seperti kebiasaan masyarakat setempat, kedekatan dengan tempat kerja, dan hal lainnya yang menyebabkan masyarakat merasa sudah nyaman dengan tempat tinggal mereka.

Melihat hal ini, maka perancangan harus diselesaikan dengan pendekatan yang berbasis pada perilaku masyarkat dan lingkungannya. Haryadi dan Setiawan (2014) menganjurkan penyelesaian masalah permukiman kumuh di perkotaan sebaiknya menjadi salah satu kajian utama dalam arsitektur perilaku-lingkungan, mengingat kompleksnya hubungan antara aspek sosial-budaya masyarakat dengan lingkungan pada kasus rumah susun perkotaan. Arsitektur perilaku-lingkungan itu sendiri merupakan arsitektur yang mengkaji bagaimana hubungan masyarakat terhadap lingkungannya yang didasarkan pada kognisi masing-masing indvidu. Dengan arsitektur perilaku akan diketahui seting lingkungan yang diinginkan oleh masyarakat dan peta-peta perilaku yang dapat dijadikan sebagai kriteria dalam menghasilkan rancangan yang lebih berdasarkan kepada pengguna bangunan.

Berdasarkan penejelasan yang sudah dipaparkan maka yang menjadi pokok permasalahan utama dalam penelitian antara lain: (1) Mengetahui setting lingkungan permukiman yang diinginkan oleh masyarakat, (2) Mengetahui setting perilaku masyarakat, (3) Merancang permukiman Kampung Aur

berdasarkan setting lingkungan dan setting perilaku yang telah diperoleh.

\section{METODE PENELITIAN}

Adapun metode penelitian yang dipergunakan dibuat berdasarkan proses riset dan perencanaan lingkungan (RPL) yang dikemukakan oleh Cherulnik (Haryadi dan Setiawan, 2014). Namun akan dilakukan pengolahan lebih lanjut oleh penulis sesuai dengan kebutuhan dari objek yang diteliti, dapat dilihat pada Tabel 1.

Tabel 1. Uraian Metodologi Penelitian

\begin{tabular}{|c|c|}
\hline $\begin{array}{c}\text { Riset dan } \\
\text { Perencanaan } \\
\text { Lingkungan } \\
\text { (Cherulnik) }\end{array}$ & $\begin{array}{l}\text { Tahapan Penelitian } \\
\text { yang Dilaksanakan }\end{array}$ \\
\hline $\begin{array}{l}\text { Analisis latar } \\
\text { belakang dari acting } \\
\text { Tahapan pengumpulan } \\
\text { data berupa data } \\
\text { kependudukan, sosial, } \\
\text { ekonomi, sejarah, } \\
\text { budaya, dan kondisi } \\
\text { lingkungan Kampung }\end{array}$ & $\begin{array}{l}\text { Pengumpulan Data } \\
\text { Umum } \\
\text { Data yang dikumpulkan } \\
\text { berupa data sosial, } \\
\text { demografi, ekonomi } \\
\text { penduduk dan data } \\
\text { lingkungan serta data } \\
\text { unit hunian }\end{array}$ \\
\hline $\begin{array}{l}\text { Tujuan-tujuan } \\
\text { perilaku untuk } \\
\text { perencanaan } \\
\text { perancangan } \\
\text { Tahapan pengumpulan } \\
\text { data berupa data } \\
\text { perilaku masyarakat }\end{array}$ & $\begin{array}{l}\text { Pengumpulan Data } \\
\text { Perilaku } \\
\text { Data perilaku yang } \\
\text { dihasilkan adalah berupa } \\
\text { data deskripsi ruang dan } \\
\text { data deskripsi perilaku }\end{array}$ \\
\hline $\begin{array}{l}\text { Hubungan } \\
\text { lingkungan dan } \\
\text { perilaku yang relevan } \\
\text { Penambahan teori-teori } \\
\text { ataupun pendekatan } \\
\text { lainnya rang } \\
\text { diperlukan. }\end{array}$ & $\begin{array}{l}\text { Yang dapat membantu } \\
\text { dalam mengembangkan } \\
\text { perencanaan antara lain : } \\
\text { analisa crowding, figure } \\
\text { ground, cakupan lokasi } \\
\text { pekerjaan dan kondisi } \\
\text { banjir di Kampung Aur }\end{array}$ \\
\hline $\begin{array}{l}\text { Rancangan } \\
\text { spesifik/komponen } \\
\text { perencanaan } \\
\text { Penerapan hasil analisa } \\
\text { yang diperoleh dalam } \\
\text { bentuk kriteria-kriteria } \\
\text { perancangan }\end{array}$ & $\begin{array}{lr}\text { Analisa Potensi dan } \\
\text { Permasalahan } \\
\text { Analisa dilakukan } \\
\text { terhadap r kedua } \\
\text { kelompok data } & \text { perilaku } \\
\text { yang diperoleh } & \text { (deskripsi } \\
\text { ruang dan } & \text { deskripsi } \\
\text { perilaku) } & \text { sehingga } \\
\text { dihasilkan } & \text { kriteria } \\
\text { perancangan } & \text { untuk } \\
\text { hunian dan lingkungan. }\end{array}$ \\
\hline
\end{tabular}


Yang menjadi populasi penelitian adalah etnis masyarakat yang ada di permukiman Kampung
Aur, sedangkan sampelnya akan diambil dengan metode purposive sampling dimana sampel akan diambil dari masing-masing keluarga dari setiap etnis dengan tipe hunian yang berbeda antara satu dengan yang lain.

Untuk lebih jelasnya metode penelitian yang dilaksanakan dapat dilihat dalam Gambar 1.

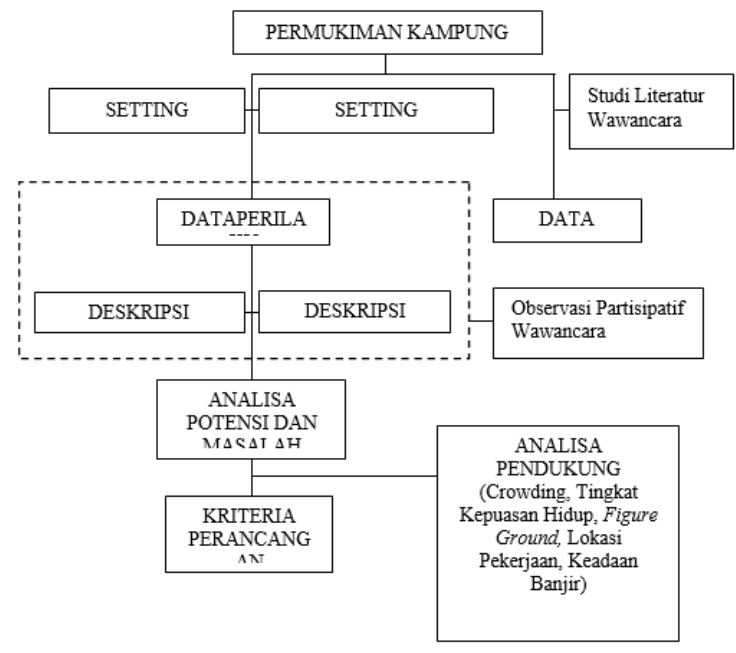

Gambar 1. Tahapan Metodologi Penelitian

\section{HASIL DAN PEMBAHASAN}

\section{Tinjauan Kawasan Permukiman Kampung Aur \\ Permukiman Kampung Aur merupakan} salah satu lingkungan (lingkungan IV) dari Kelurahan Aur, Kecamatan Medan Maimun, Kota Medan. Permukiman ini terletak di antara simpang Jalan Letjen Suprapto dan Jalan Brigjen Katamso, dapat dilihat pada Gambar 2.

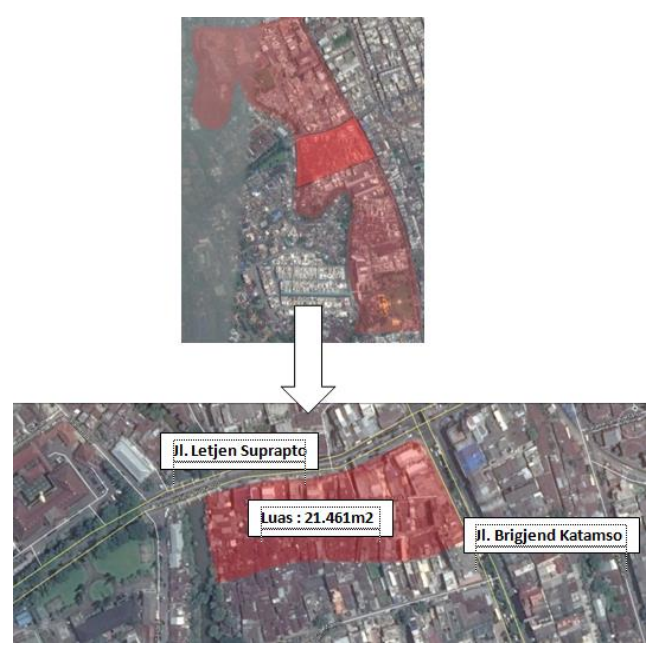

Gambar 2. Peta Lokasi Kampung Aur

Secara umum diketahui bahwa permukiman Kampung Aur didominasi oleh dua
(2) etnis utama yaitu: etnis Minang dan etnis Cina. Seperti dapat dilihat pada Gambar 3.

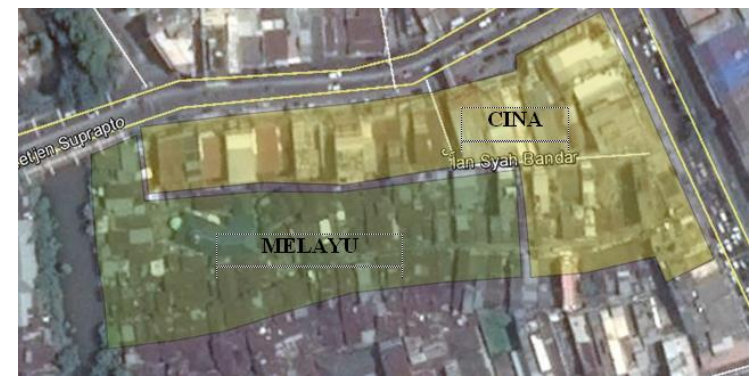

Gambar 3. Pembagian Kawasan Hunian Berdasarkan Etnis

Permukiman etnis Minang terbagi menjadi dua bagian besar yaitu rumah tinggal yang berfungsi sebagai rumah tinggal saja dan rumah tinggal yang sekaligus berfungsi sebagai tempat usaha. Sebanyak $74,07 \%$ hunian yang ada di Kampung Aur merupakan milik dari penduduk etnis Minang dan sebesar 91,42\% penduduk Kampung Aur merupakan penduduk etnis Minang.

Untuk penduduk etnis Cina, tipologi huniannya terbagi menjadi tiga (3) bagian yaitu ruko, hunian saja serta hunian yang berfungsi ganda sebagai tempat usaha. Sebanyak $24,6 \%$ hunian yang ada di Kampung Aur dimiliki oleh 
penduduk etnis Cina dan sebesar 7,8\% penduduk Kampung Aur beretnis Cina.

Disamping kedua etnis di atas juga terdapat etnis penduduk lainnya seperti penduduk etnis Manado, Tamil dan Nias, namun jumlahnya sangat sedikit, dimana masingmasing etnis terdiri dari satu (1) keluarga saja, sehingga tidak memiliki pengaruh yang begitu signifikan untuk dijadikan sampel dari objek penelitian.

Selain melihat etnis yang dominan serta masing-masing tipologi huniannya, dari hasil observasi yang dilakukan juga ditemui ada beberapa komponen lingkungan yang dianggap penting dan langsung berdampak terhadap perilaku masyarkat di Kampung Aur. Adapun komponen lingkungan yang dimaksud antara lain : (1) Warung yang memiliki berbagai fungsi antara lain sebagai tempat berkumpul masyarakat; (2) Ruang bermain anak; (3) Sisa ruang antar bangunan yang dijadikan sebagai tempat berinteraksi; (4) Pelataran mesjid; (5) Tempat jajanan malam; (6) Bantaran Sungai; (7) Jalan yang juga memiliki fungsi lain seperti tempat terjadinya interaksi dan kegiatan ekonomis. Untuk lebih lengkapnya dapat dilihat pada gambar 4.
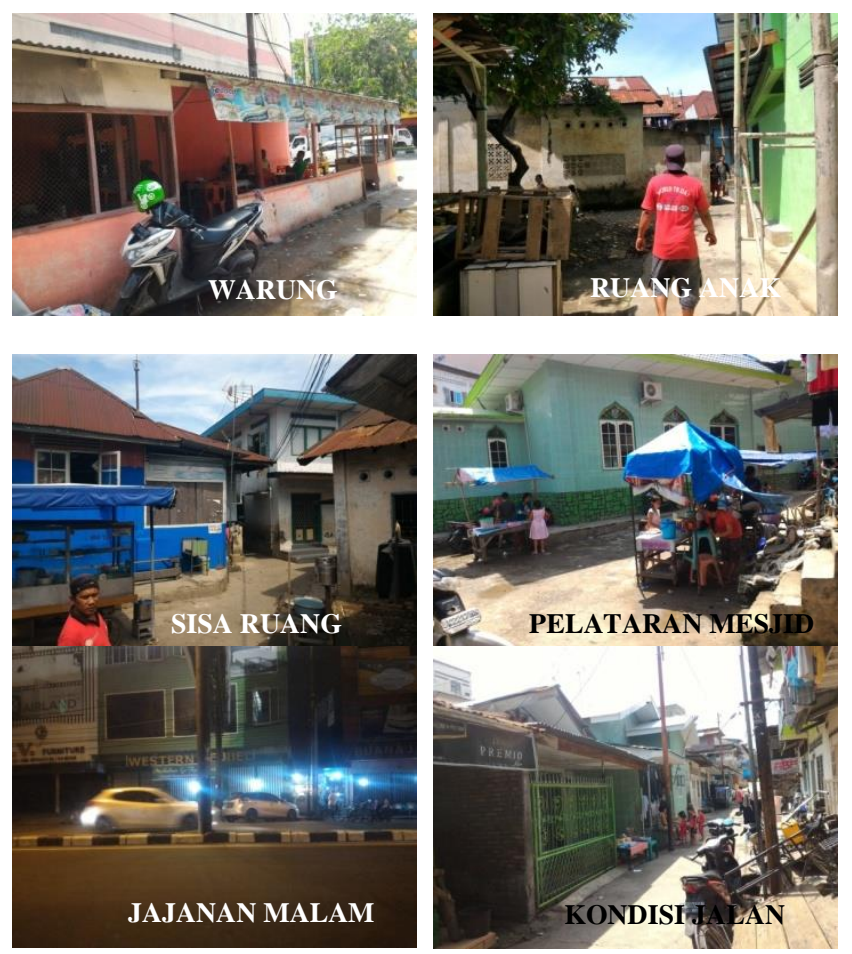

Gambar 4. Komponen Lingkungan di Permukiman Kampung Aur

\section{Eksplorasi Perilaku Masyarakat Etnis Minang pada Unit Huniannya}

Eksplorasi perilaku masyarakat etnis Minang pada huniannya dilakukan terhadap sepuluh (10) keluarga sebagai sampelnya. Namun berikut akan dijelakan perilaku pada salah satu keluarga saja sebagai pembandingnya (Tabel 2).

Tabel 2. Keluarga Etnis Minang (Surya Sumardi)

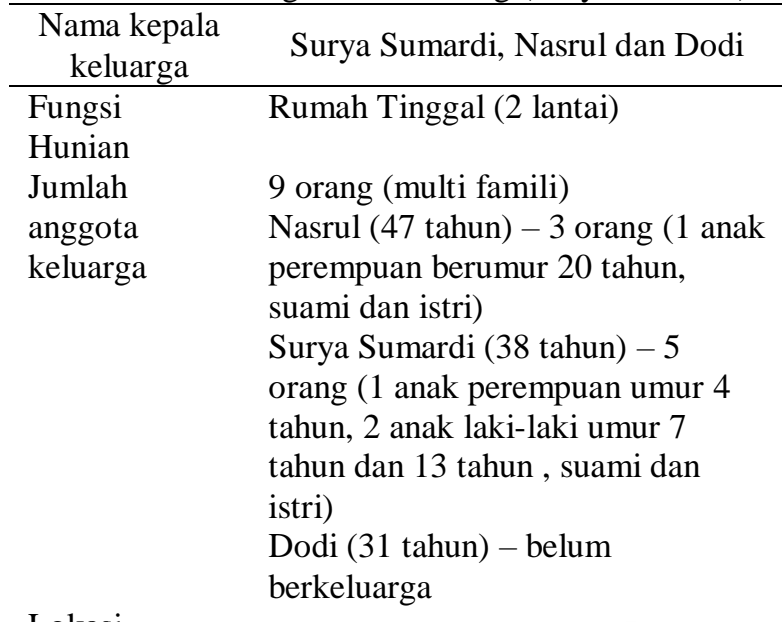

Pekerjaan Nasrul dan istri bekerja sebagai pedagang musiman dan pada saat dilakukan pengamatan sedang menekuni pekerjaan sebagai pembuat gula merah. Anak perempuannya bekerja sebagai pegawai di salah satu supermarket di dekat Kampung Aur.

Surya Sumardi bekerja sebagai pegawai keamanan di perusahaan swasta di dekat lokasi penelitian dan isterinya sebagai ibu rumah tangga sekaligus menjual kartu untuk kuota internet. 2 anak lakilakinya masih bersekolah di tingkat SD dan SMP sedangkan anak perempuannya belum bersekolah. 


\begin{tabular}{|c|c|}
\hline $\begin{array}{c}\text { Nama kepala } \\
\text { keluarga }\end{array}$ & Surya Sumardi, Nasrul dan Dodi \\
\hline & $\begin{array}{l}\text { Dodi bekerja sebagai pekerja } \\
\text { serabutan. Pada saat penelitian } \\
\text { dilakukan sedang bekerja sebagai } \\
\text { pekerja bangunan di RT sebelah } \\
\text { (masih di Kelurahan Aur juga) }\end{array}$ \\
\hline
\end{tabular}

\begin{tabular}{ll}
\hline Riwayat & Rumah ini merupakan rumah \\
Keluarga & peninggalan orang tua terhadap \\
& ketiga anaknya (istri Surya \\
& Sumardi, Nasrul dan Dodi) yang \\
& bersuku Melayu. \\
& Nasrul merupakan anak pertama \\
& diikuti istri Surya Sumardi dan \\
& Dodi. \\
\hline
\end{tabular}

Hunian keluarga Surya Sumardi merupakan hunian dua (2) lantai dimana pada bagian depannya (ruang tamu) juga dipergunakan sebagai tempat penjualan pulsa. Untuk membantu visualisasi akan unit huniannya (Gambar 5).

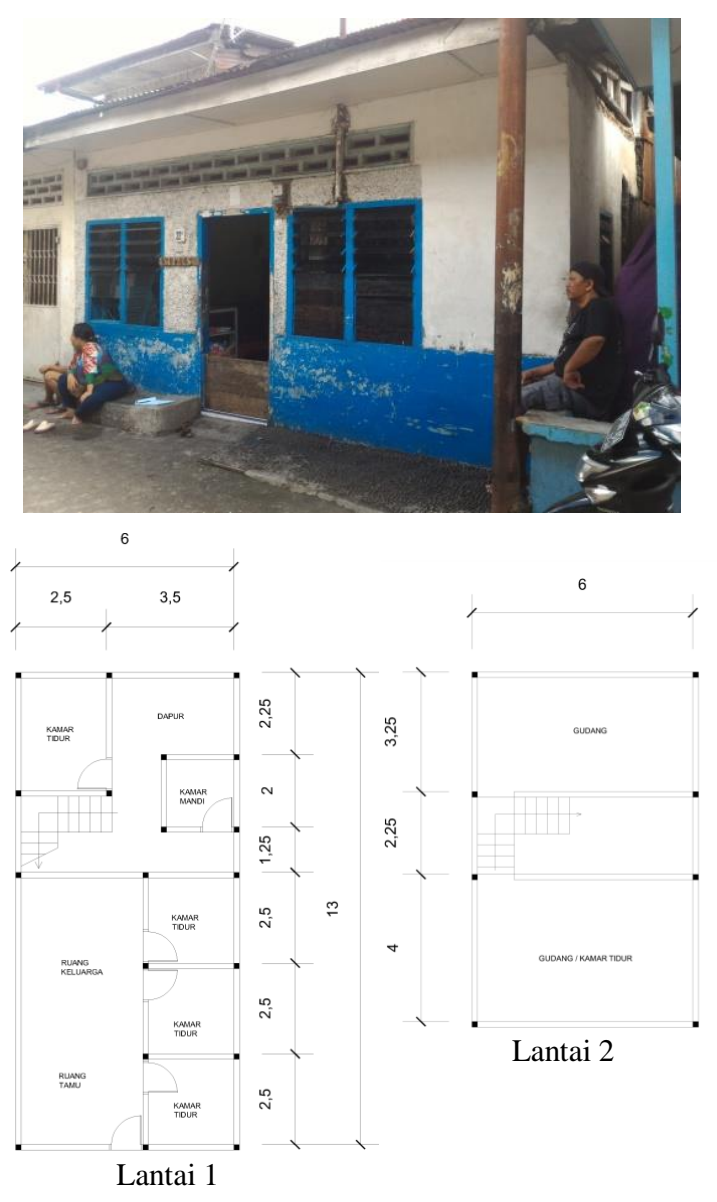

Gambar 5. Tampak dan Denah Hunian Keluarga Surya Sumardi
Dari hasil observasi partisipatif yang dilakukan, didapatkan deskripsi ruang dan deskripsi perilaku (Tabel 3 dan 4).

Tabel 3. Deskripsi Ruang Keluarga Surya Sumardi

\begin{tabular}{l} 
Deskripsi Ruang \\
\hline Ukuran dan Bentuk Ruang \\
Pada ruang tamu/keluarga, kamar tidur dan dapur pada \\
umumnya sifatnya fleksibel mengikuti kebutuhan \\
penghuni rumah, teras sifatnya terbuka dan kamar \\
mandi umumnya kurang memenuhi standar. Sedangkan \\
untuk penambahan ruang biasanya sejalan dengan \\
pertambahan jumlah keluarga dan biasanya \\
menggunakan bahan semi permanen.
\end{tabular}

\section{Perletakan Perabotan}

Pada ruang tamu/ruang keluarga, dapur dan kamar mandi perletakan perabotan fleksibel dan cenderung tidak teratur. Hanya kamar yang memiliki pengaturan perabotan tertentu

\section{Warna}

Pemilihan warna cerah untuk bagian luar dan dalam ruangan, kecuali kamar tidur biasanya memiliki warna putih

\section{Temperatur}

Kondisi penghawaan secara alami minim

Pencahayaan

Kondisi pencahayaan secara alami minim

Kebisingan

Tidak ada perlakuan khusus untuk masalah kebisingan

Tabel 4. Deskripsi Perilaku Keluarga Surya Sumardi

\begin{tabular}{l} 
Deskripsi Perilaku \\
\hline Pola Aktivitas Penghuni Rumah \\
Penghuni pada umumnya memiliki pekerjaan tidak \\
tetap dan cenderung berubah-ubah. Hal ini berpengaruh \\
secara langsung terhadap perubahan fungsi ruang serta \\
perletakan perabotan di tiap ruangan
\end{tabular}

\section{Privasi/Teritori}

Pada masyarakat Minang pada umumnya privasi masing-masing unit hunian hanya terdapat pada bagian kamar tidur masing-masing, sedangkan untuk ruang tamu dan ruang lainnya sifatnya biasanya berada pada ruang publik ataupun semi publik/privat.

Hal ini menyebabkan rasa kebersamaan dan rasa saling memiliki yang tinggi. Kemudahan dalam melaksanakan kegiatan yang sifatnya kegiatan bersama.
Aktivitas Sosial di Teras Rumah
Teras rumah pada umumnya digunakan sebagai tempat bersosialisasi oleh ibu-ibu rumah tangga pada sore hari Penambahan Ruang
Penambahan ruang didasarkan pada penambahan jumlah anggota keluarga yang sudah berkeluarga 


\section{Penentuan Jumlah Kamar Tidur}

Selain jumlah anggota keluarga yang sudah memiliki keluarga sendiri, pertambahan jumlah kamar juga dipengaruhi oleh ada atau tidaknya anak perempuan yang sudah dewasa.

\section{Eksplorasi Perilaku Masyarakat Etnis Cina pada Unit Huniannya}

Eksplorasi perilaku masyarakat etnis Cina pada huniannya dilakukan terhadap delapan (8) keluarga sebagai sampelnya. Namun berikut akan dijelakan perilaku pada salah satu keluarga saja sebagai pembandingnya (Tabel 5).

Tabel 5. Keluarga Etnis Cina (Eni Tenggara)

\begin{tabular}{ll}
\multicolumn{1}{c}{$\begin{array}{c}\text { Nama kepala } \\
\text { keluarga }\end{array}$} & \multicolumn{1}{c}{ Eni Tenggara } \\
\hline $\begin{array}{l}\text { Fungsi } \\
\text { Hunian }\end{array}$ & Rumah Tinggal (1 lantai) \\
Jumlah & 5 orang (single famili) \\
anggota & Suami - sudah meninggal dunia \\
keluarga & Isteri (57 tahun) - Eni Tenggara \\
& Anak Perempuan (18 tahun) \\
& Anak laki-laki I (30 tahun) - sudah \\
& berkeluarga dan tinggal di luar kota \\
& Anak laki-laki II (26 tahun) - sudah \\
& berkeluarga dan tinggal di luar kota.
\end{tabular}

Lokasi

Pekerjaan

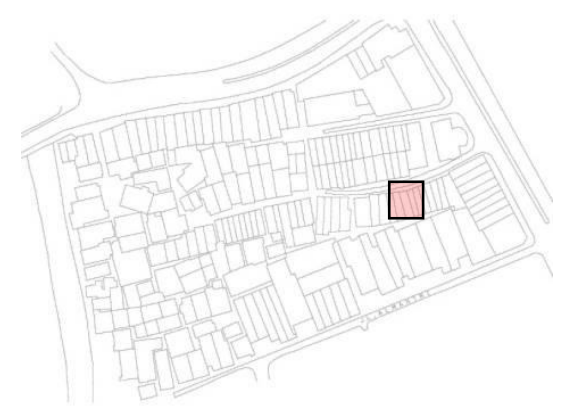

Eni Tenggara bekerja sebagai ibu rumah tangga, dimana sekarang masalah keuangan sudah banyak dibantu oleh anak laki-laki yang sudah bekerja. Sebelumnya bersama suami berdagang di pajak sambas di dekat lokasi (membuka kios).

Anak Perempuan belajar di tingkat pendidikan Sekolah Menegah Atas (SMA)

Riwayat Rumah ini merupakan rumah yang Keluarga dibeli oleh Eni Tenggara dan suaminya pada sekitar tahun 2003. Sebelumnya menyewa rumah juga tidak jauh dari lokasi sekarang

Hunian keluarga Eni Tenggara merupakan hunian satu (1) lantai. Hanya berfungsi sebagai rumah tinggal saja dan hanya dihuni oleh dua (2) orang. Untuk membantu visualisasi akan unit huniannya (Gambar 6).
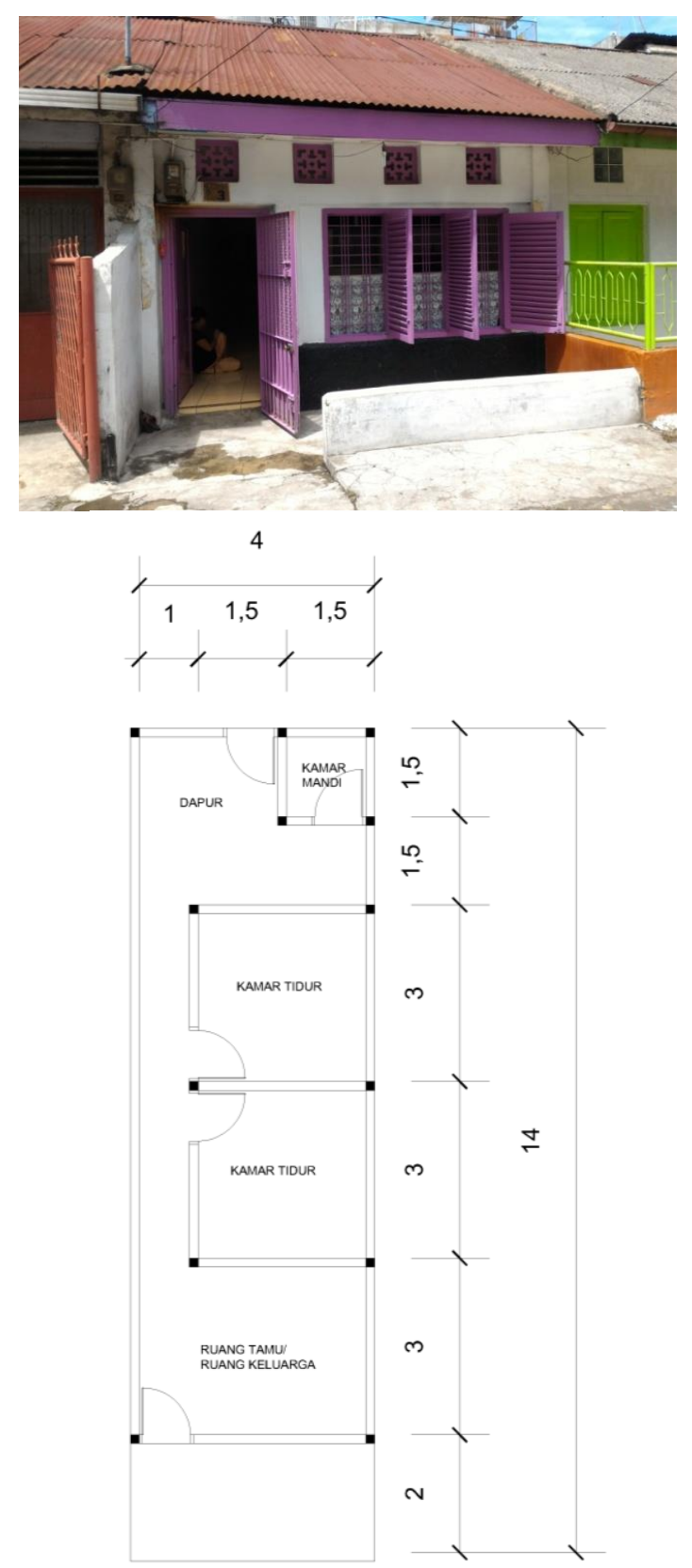

Gambar 6. Tampak dan Denah Hunian Keluarga Enit Tenggara

Dari hasil observasi partisipatif yang dilakukan, didapatkan deskripsi ruang dan deskripsi perilaku (Tabel 6 dan 7). 
Tabel 6. Deskripsi Ruang Keluarga Eni Tenggara

\section{Deskripsi Ruang}

\section{Ukuran dan Bentuk Ruang \\ Bentuk dan ukuran ruang cukup fleksibel, namun sudah mempunyai fungsi yang tetap, artinya ruang tamu akan berfungsi sebagai ruang tamu dan tidak akan digunakan sebagai ruang tidur tambahan ,ruang berjualan ataupun ruang lainnya.}

\section{Perletakan Perabotan}

Jika dilihat dari pengamatan yang sudah dilakukan, perletakan perabot terkadang masih kurang beraturan namun tidak sejauh seperti yang terjadi pada pemukiman etnis Minang

\section{Warna}

Pemilihan warna cerah untuk bagian luar dan dalam ruangan, kecuali kamar tidur biasanya memiliki warna putih

\section{Temperatur}

Kondisi penghawaan secara alami sedang

Pencahayaan

Kondisi pencahayaan secara alami sedang

\section{Kebisingan}

Tingkat kebisingan cukup rendah, hal ini terkait dengan privasi yang tinggi. Ini juga tercermin dalam penggunaan material permanen dalam penyekat ruangan

Tabel 7. Deskripsi Perilaku Keluarga Eni Tenggara

\section{Deskripsi Perilaku}

Pola Aktivitas Penghuni Rumah
Penghuni pada umumnya memiliki pekerjaan
tetap ataupun memiliki aktivitas yang sudah tetap
sepanjang hari, ini akan langsung berpengaruh
terhadap aktivitas yang terjadi di dalam ruangan
Privasi/Teritori
Pada masyarakat etnis Cina privasi bisa dikatakan
sangat tinggi. Sangat tidak suka jika ruang
pribadinya dimasuki oleh orang lain.Hal ini
menyebabkan rasa kebersamaan yang kurang
serta interaksi dengan masyarakat etnis lain yang
rendah.
Interaksi Sosial yang Sangat Minim
Interaksi sosial sangat minim terjadi dan hanya
mungkin terjadi pada bagian teras depan rumah.
Kebiasaan Menanam Tanaman
Kebanyakan masyarakat etnis Cina
menyempatkan diri untuk menanam dan merawat
tanaman yang memang sengaja ditata di bagian
depan teras rumah

\section{Eksplorasi Perilaku Masyarakat Kampung Aur terhadap Lingkungannya}

Untuk komponen lingkungan yang sudah disampaikan sebelumnya, berdasarkan hasil observasi partisipatif yang dilakukan, maka didapatkan bentuk-bentuk aktivitas yang biasanya terjadi pada komponen-komponen lingkungan tersebut (Tabel 8).

Tabel 8. Komponen Lingkungan dan Aktivitas yang Diwadahinya

\begin{tabular}{|c|c|}
\hline $\begin{array}{l}\text { Komponen } \\
\text { Lingkungan }\end{array}$ & Aktivitas yang Diwadahi \\
\hline Warung & 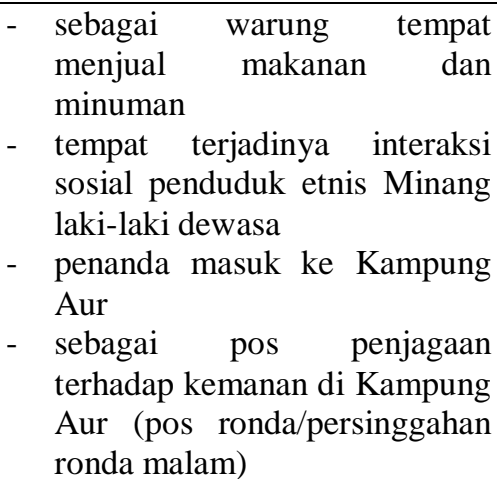 \\
\hline $\begin{array}{l}\text { Ruang } \\
\text { Terbuka Anak }\end{array}$ & $\begin{array}{l}\text { - ruang terbuka ini adalah akan } \\
\text { dibuat langsung berhubungan } \\
\text { dengan tempat belajar mengaji, } \\
\text { yang juga langsung } \\
\text { berhubungan dengan pelataran } \\
\text { Mesjid. Dengan menghidupkan } \\
\text { ruang terbuka anak ini juga } \\
\text { diharapkan dapat mengurangi } \\
\text { kemungkinan timbulnya } \\
\text { patologi sosial yang berlokasi } \\
\text { tidak jauh dari ruang terbuka } \\
\text { ini melalui sistem "natural } \\
\text { surveillance" }\end{array}$ \\
\hline Ruang & - $\quad$ sebagai tempat PKL berjualan \\
\hline Terbuka & - sebagai tempat berkumpul dan \\
\hline Umum & $\begin{array}{l}\text { terjadinya interaksi sosial } \\
\text { penduduk etnis Minang di } \\
\text { Kampung Aur } \\
\text { - sebagai "pengawas" terhadap } \\
\text { kegiatan yang terjadi di ruang } \\
\text { terbuka anak, mengingat } \\
\text { letaknya yang langsung } \\
\text { berbatasan }\end{array}$ \\
\hline $\begin{array}{l}\text { Pelataran } \\
\text { Mesjid }\end{array}$ & 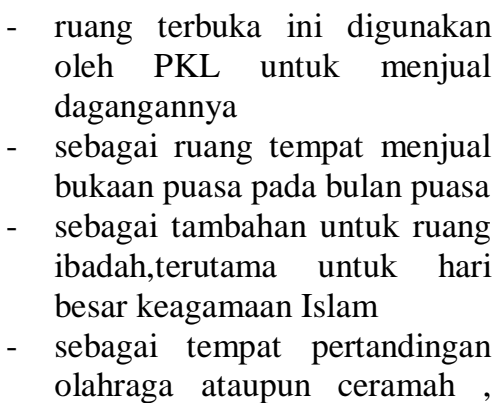 \\
\hline
\end{tabular}




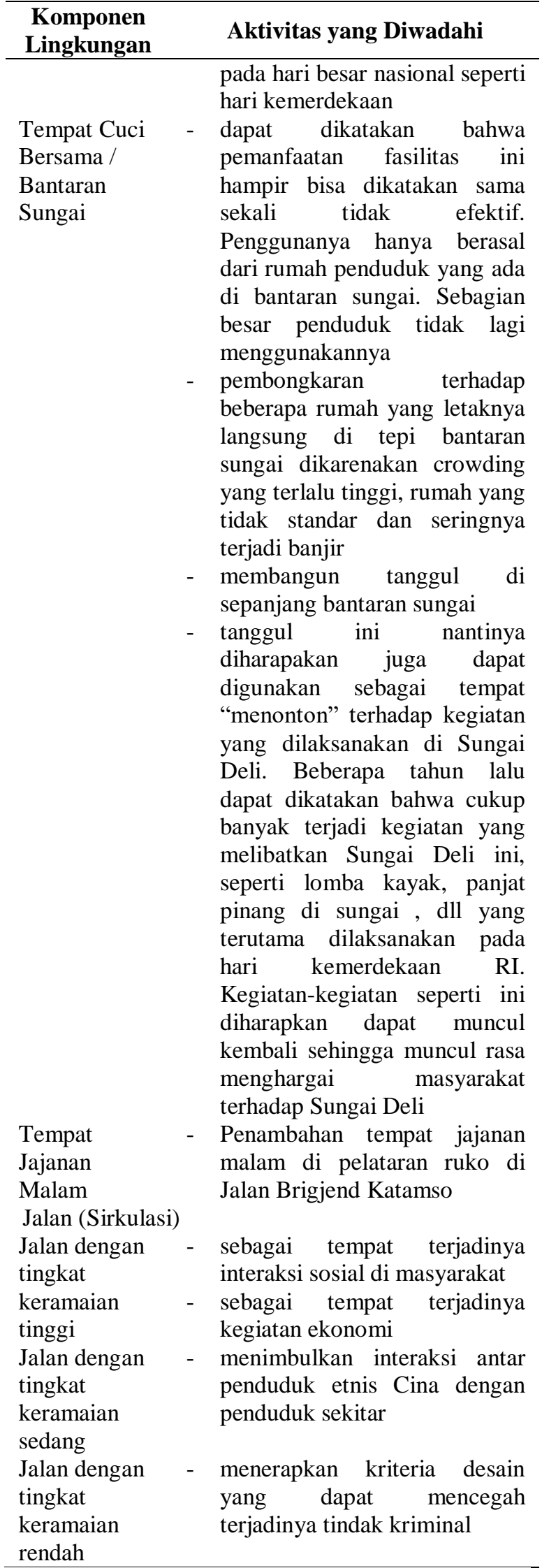

\section{Analisa Pendukung (Crowding, Tingkat Kepadatan, Kepuasan Hidup,}

\section{Cakupan Lokasi Pekerjaan dan Keadaan Banjir)}

Analisa pendukung ini berfungsi untuk memberikan input tambahan terhadap data perilaku dan data ruang yang sudah dikumpulkan. Dengan adanya analisa pendukung ini, dapat diketahui bagaimana tipologi bangunan yang tepat untuk permukiman Kampung Aur, Tingkat ketergantungan pekerjaan terhadap lokasi tempat tinggal, Keadaan banjir dan bantaran sungai, serta adapatasi masyarakat terhadap kehidupan di Kampung Aur (Tabel 9).

Tabel 9. Analisa Pendukung

\begin{tabular}{|c|c|}
\hline $\begin{array}{c}\text { Analisa } \\
\text { Pendukung }\end{array}$ & Hasil Analisa \\
\hline Crowding & $\begin{array}{l}\text { - } \text { Tidak banyak indikasi } \\
\text { munculnya penyakit psikis } \\
\text { dan fisik } \\
\text { - Ada indikasi munculnya } \\
\text { patologi sosial terutama di } \\
\text { daerah bantaran sungai dan } \\
\text { daerah yang sepi (belakang } \\
\text { ruko Letjen Suprapto) } \\
\text { - Ada indikasi munculnya } \\
\text { tingkah laku sosial negatif } \\
\text { terutama di daerah bantaran } \\
\text { sungai }\end{array}$ \\
\hline $\begin{array}{l}\text { Tingkat } \\
\text { Kepuasan } \\
\text { Hidup }\end{array}$ & $\begin{array}{l}\text { - Sebagian besar penduduk } \\
\text { merasa cukup puas tinggal di } \\
\text { Kampung Aur }\end{array}$ \\
\hline $\begin{array}{l}\text { Figure } \\
\text { Ground }\end{array}$ & $\begin{array}{l}\text { - Walaupun termasuk } \\
\text { permukiman yang padat, } \\
\text { tetapi masih dimungkinkan } \\
\text { untuk dilakukan peningkatan } \\
\text { bangunan hingga menjadi } 2 \\
\text { atau } 3 \text { lantai. Belum } \\
\text { diperlukan adanya bangunan } \\
\text { massal vertikal dalam waktu } \\
\text { dekat ini. }\end{array}$ \\
\hline $\begin{array}{l}\text { Cakupan } \\
\text { Lokasi } \\
\text { Pekerjaan }\end{array}$ & $\begin{array}{l}\text { - Sebagian besar penduduk } \\
\text { memiliki mata pencaharian } \\
\text { yang terletak dekat atau di } \\
\text { Kampung Aur, sehingga jika } \\
\text { ada rencana relokasi hal ini } \\
\text { harus dipertimbangkan. }\end{array}$ \\
\hline $\begin{array}{l}\text { Keadaan } \\
\text { Banjir }\end{array}$ & 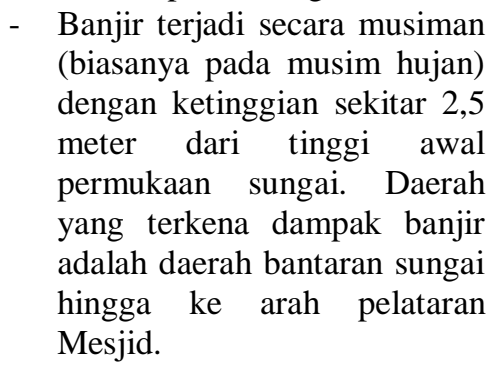 \\
\hline
\end{tabular}




\section{Kriteria Perancangan Permukiman lingkungan serta analisa pendukung yang sudah Kampung Aur dilakukan (Tabel 10-12).}

Dari hasil eksplorasi perilaku masyarakat terhadap setting unit hunian dan setting

Tabel 10. Kriteria Perancangan Permukiman Etnis Minang di Kampung Aur

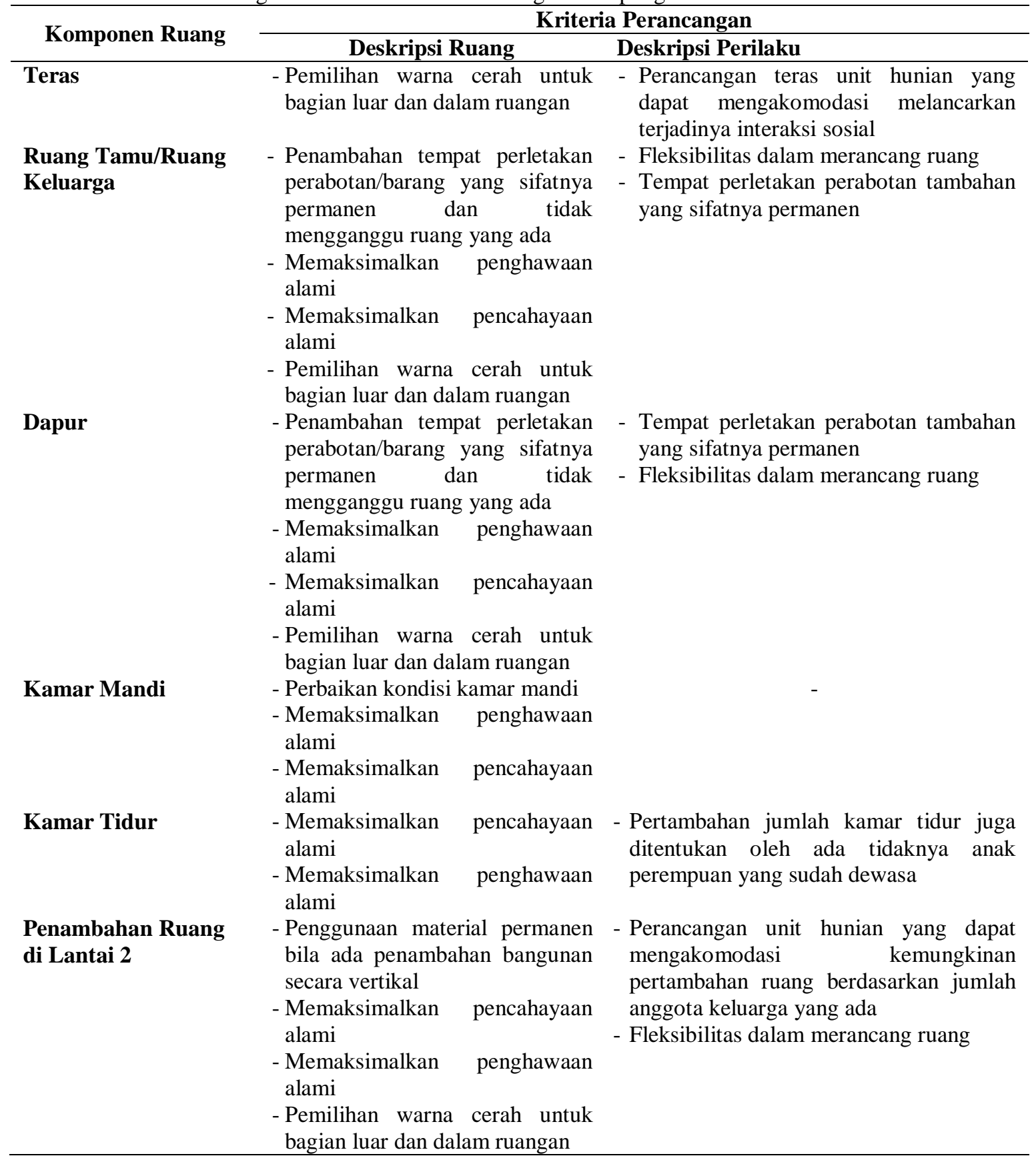

Tabel 11. Kriteria Perancangan Permukiman Etnis Cina di Kampung Aur

\begin{tabular}{llc}
\hline Komponen Ruang & \multicolumn{2}{c}{ Kriteria Perancangan } \\
\cline { 2 - 3 } & Deskripsi Ruang & Deskripsi Perilaku \\
\hline Teras & - Pemilihan warna cerah untuk bagian & - Perancangan teras unit hunian yang \\
& luar dan dalam ruangan & dapat meningkatkan interaksi sosial \\
& & antar tetangga \\
& & Perancangan unit hunian yang dapat \\
& & mengakomodasi kebiasaan merawat
\end{tabular}




\begin{tabular}{|c|c|c|}
\hline \multirow[t]{2}{*}{ Komponen Ruang } & \multicolumn{2}{|c|}{ Kriteria Perancangan } \\
\hline & Deskripsi Ruang & Deskripsi Perilaku \\
\hline $\begin{array}{l}\text { Ruang } \\
\text { Tamu/Ruang } \\
\text { Keluarga }\end{array}$ & $\begin{array}{l}\text { - Penambahan tempat perletakan } \\
\text { perabotan/barang yang sifatnya } \\
\text { permanen dan tidak mengganggu } \\
\text { ruang yang ada } \\
\text { - Pemilihan warna cerah untuk bagian } \\
\text { luar dan dalam ruangan }\end{array}$ & $\begin{array}{l}\text { tanaman } \\
\text { - Pembagian fungsi ruang yang jelas } \\
\text { - Tempat perletakan perabotan tambahan } \\
\text { yang sifatnya permanen } \\
\text { - Perancangan unit hunian yang dapat } \\
\text { menjaga privasi penghuni }\end{array}$ \\
\hline Dapur & $\begin{array}{l}\text { - Penambahan tempat perletakan } \\
\text { perabotan/barang yang sifatnya } \\
\text { permanen dan tidak mengganggu } \\
\text { ruang yang ada } \\
\text { - Memaksimalkan penghawaan alami } \\
\text { - Memaksimalkan pencahayaan alami } \\
\text { - Pemilihan warna cerah untuk bagian } \\
\text { luar dan dalam ruangan }\end{array}$ & $\begin{array}{l}\text { - Tempat perletakan perabotan } \\
\text { tambahan yang sifatnya permanen }\end{array}$ \\
\hline Kamar Mandi & $\begin{array}{l}\text { - Memaksimalkan penghawaan alami } \\
\text { - Memaksimalkan pencahayaan alami }\end{array}$ & - \\
\hline Kamar Tidur & $\begin{array}{l}\text { - Memaksimalkan pencahayaan alami } \\
\text { - Memaksimalkan penghawaan alami }\end{array}$ & $\begin{array}{l}\text { - Perancangan unit hunian yang dapat } \\
\text { menjaga privasi penghuni }\end{array}$ \\
\hline
\end{tabular}

Tabel 12. Kriteria Perancangan Lingkungan di Kampung Aur

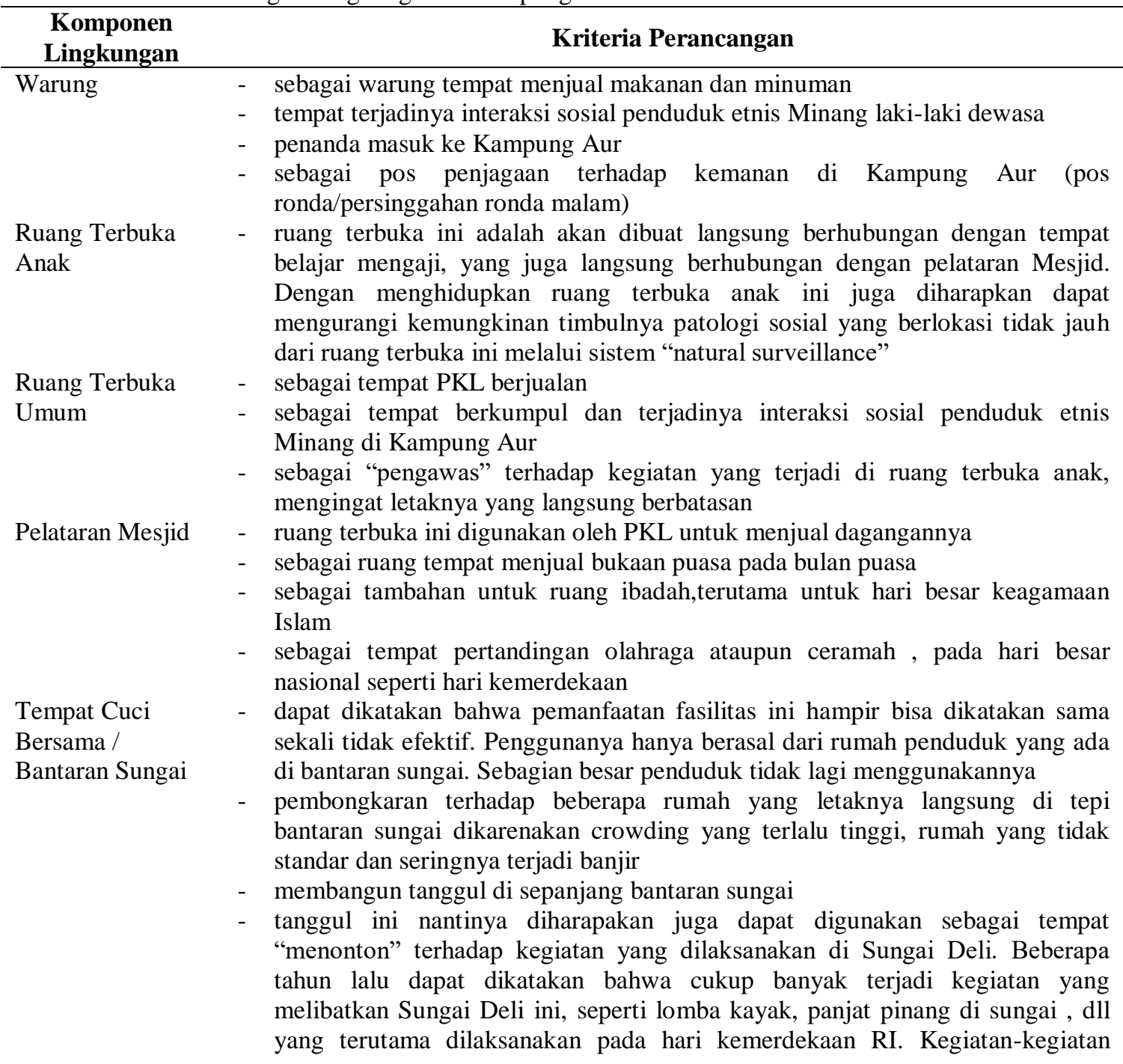




\begin{tabular}{|c|c|}
\hline $\begin{array}{l}\text { Komponen } \\
\text { Lingkungan }\end{array}$ & Kriteria Perancangan \\
\hline $\begin{array}{l}\text { Tempat Jajanan } \\
\text { Malam }\end{array}$ & $\begin{array}{l}\text { seperti ini diharapkan dapat muncul kembali sehingga muncul rasa menghargai } \\
\text { masyarakat terhadap Sungai Deli } \\
\text { - } \quad \text { Penambahan tempat jajanan malam di pelataran ruko di Jalan Brigjend Katamso }\end{array}$ \\
\hline $\begin{array}{l}\text { Jalan (Sirkulasi) } \\
\text { Jalan dengan } \\
\text { tingkat keramaian } \\
\text { tinggi }\end{array}$ & $\begin{array}{l}\text { - } \quad \text { sebagai tempat terjadinya interaksi sosial di masyarakat } \\
\text { - } \quad \text { sebagai tempat terjadinya kegiatan ekonomi }\end{array}$ \\
\hline $\begin{array}{l}\text { Jalan dengan } \\
\text { tingkat keramaian } \\
\text { sedang } \\
\text { Jalan dengan } \\
\text { tingkat keramaian } \\
\text { rendah }\end{array}$ & $\begin{array}{l}\text { - menimbulkan interaksi antar penduduk etnis Cina dengan penduduk sekitar } \\
\text { - menerapkan kriteria desain yang dapat mencegah terjadinya tindak kriminal }\end{array}$ \\
\hline
\end{tabular}

\section{KESIMPULAN}

Adapun kesimpulan yang diperoleh dari penelitian yang sudah dilakukan antara lain:

1. Penduduk etnis Minang adalah kelompok penduduk yang sifatnya dinamis, memiliki tingkat interaksi sosial yang tinggi, mempunyai teritorialitas yang sangat tinggi dan tingkat privasi yang rendah. Dapat dikatakan karakter ini sama sekali tidak mencerminkan karakter penduduk kota besar pada umumnya, beberapa ahli mengatakan bahwa ini adalah karakteristik penduduk yang terdapat pada "Kampung Kota".

2. Penduduk etnis Cina sebaliknya memiliki karakteristik penduduk kota besar pada umunya, sifatnya individualistis, tingkat interaksi sosial yang rendah dan lebih banyak beraktivitas di luar rumah.

3. Terdapat 6 (enam) komponen lingkungan yang secara langsung mempengaruhi aktivitas/perilaku hidup masyarakat di Kampung Aur antara lain: (1) warung yang ada pada pintu masuk menuju Kampung Aur; (2) ruang terbuka umum yang digunakan terutama oleh orang dewasa untuk berkumpul; (3) ruang terbuka anak yang digunakan sebagi tempat bermain oleh anakanak dan berdekatan dengan tempat pengajian; (4) ruang terbuka di Pelataran Mesjid yang terhubung langsung dengan bantaran sungai; (5) tempat jajanan malam; (6) serta karakteristik jalan berdasarkan lokasi dimana jalan tersebut berada.

\section{Daftar Pustaka}

Haryadi dan Setiawan (2014) Arsitektur, Lingkungan dan Perilaku. Yogyakarta: Gajah Mada University Press.

Rapoport, Amos (1977) Human Aspect of Urban Form. Oxford: Pergamon Press. 